\title{
Characterization of Springtime Coliform Populations at the End Creek Wetland Restoration (Union Co., Oregon, USA): A Three-Year Study
}

\author{
Joseph A. Corsini¹, Larry Rob Peters², Brian Tarpy ${ }^{1}$, Chung Pak ${ }^{1}$, Karen Antell ${ }^{1}$ \\ ${ }^{1}$ Eastern Oregon University, La Grande, USA \\ ${ }^{2}$ Aquinas College, Grand Rapids, USA \\ Email: jcorsini@eou.edu
}

Received 10 July 2015; accepted 25 August 2015; published 28 August 2015

Copyright (C) 2015 by authors and Scientific Research Publishing Inc.

This work is licensed under the Creative Commons Attribution International License (CC BY). http://creativecommons.org/licenses/by/4.0/

(c) ()) Open Access

\section{Abstract}

In 2005, a 550-acre tract of agricultural land containing two small streams near La Grande, Oregon was registered in the U.S. Federal Wetlands Reserve Program. This designation was part of a plan to reclaim and restore the wetland to its natural state. Initial efforts at the End Creek Restoration Project restored both End Creek and South Fork Willow Creek to a natural course through rechanneling, and several plantings had restored some of the native flora. Since its establishment, the End Creek streams and floodplain have become a reserve for summer steelhead (Oncorhynchus mykiss), a threatened anadromous salmonid, and many migratory birds. The threatened Columbia Spotted Frog has also established itself in some of the ponds. As part of an effort to establish a baseline for water quality, we monitored total springtime coliform and fecal coliform bacteria in three of the End Creek ponds for three years. The results of this study indicate that, throughout any given spring, the numbers of both coliform and fecal coliform bacteria can fluctuate markedly among ponds on any given day, and that in any particular pond the numbers fluctuate from week to week. In addition, our analysis suggests that in early spring, the numbers of these organisms also fluctuate from year to year. The causes of these fluctuations are not well understood, but are expected to reflect both springtime flooding and the migrations of source animals such as waterfowl and cervids. Information gathered from this study will help inform future management activities on the wetland.

\section{Keywords}

Coliform, Fecal Coliform, End Creek Wetland Restoration 


\section{Introduction}

Historically, wetlands in the U.S. have been degraded in many ways, the most common being drainage, watercourse alteration, overgrazing by cattle, chemical pollution, and contamination with raw sewage. Of the potential disruptions to wetlands, affluent human or animal sewage has particular bearing on human health because of the infectious agents that can be harbored in the contaminated waters. This is especially true of wetlands that are used by humans for recreation, drinking water, or domestic livestock because numerous pathogens can be transmitted by raw sewage. These include enteric viruses, enteropahtogencic bacteria such as Salmonella and Shigella, and a variety of protozoan pathogens including Giardia species, Encephalitozoan intestinalis, and Cryptosporidium parvum [1]-[4]. Amongst the bacteria found in raw sewage are the fecal coliforms, which normally reside in vertebrate intestines. As part of the "native flora", these microorganisms are thought to survive for only short periods of time outside the vertebrate body, and fecal coliform presence in waterways is assumed to represent recent or ongoing fecal contamination [4] [5]. Because their presence in waterways indicates the presence of vertebrate feces, they are used as indicators of fecal contamination in aquatic systems. Fecal coliforms have also been studied in a broader ecological context with a view toward assessing the state of human fecal contaminants in watersheds and wetlands (for example, see [6]-[9]). This is because in addition to human health effects, extensive fecal contamination through human sewage or domestic animal waste can cause eutrophication events that adversely influence aquatic ecosystems, causing algal and/or cyanobacterial blooms that release toxic substances into the water and increase the biological oxygen demand, killing fish and aquatic invertebrates [10]-[12]. As a result, fecal coliform monitoring is often used to track sewage influx during assessment of wetlands (for example, see [4] [7] [13] [14]).

In recent years, significant strides have been taken toward protecting and restoring damaged wetland ecosystems in the U.S. One such restoration effort is the End Creek Wetland Restoration Project near La Grande in Northeast Oregon. Initiated in 2006, this project aims to restore a 550-acre farm to its natural state. As part of this effort, the land was enrolled in the Wetlands Reserve Program that same year, which guaranteed permanent protection from future development. The project includes eight ponds and two small creeks (Figure 1). The

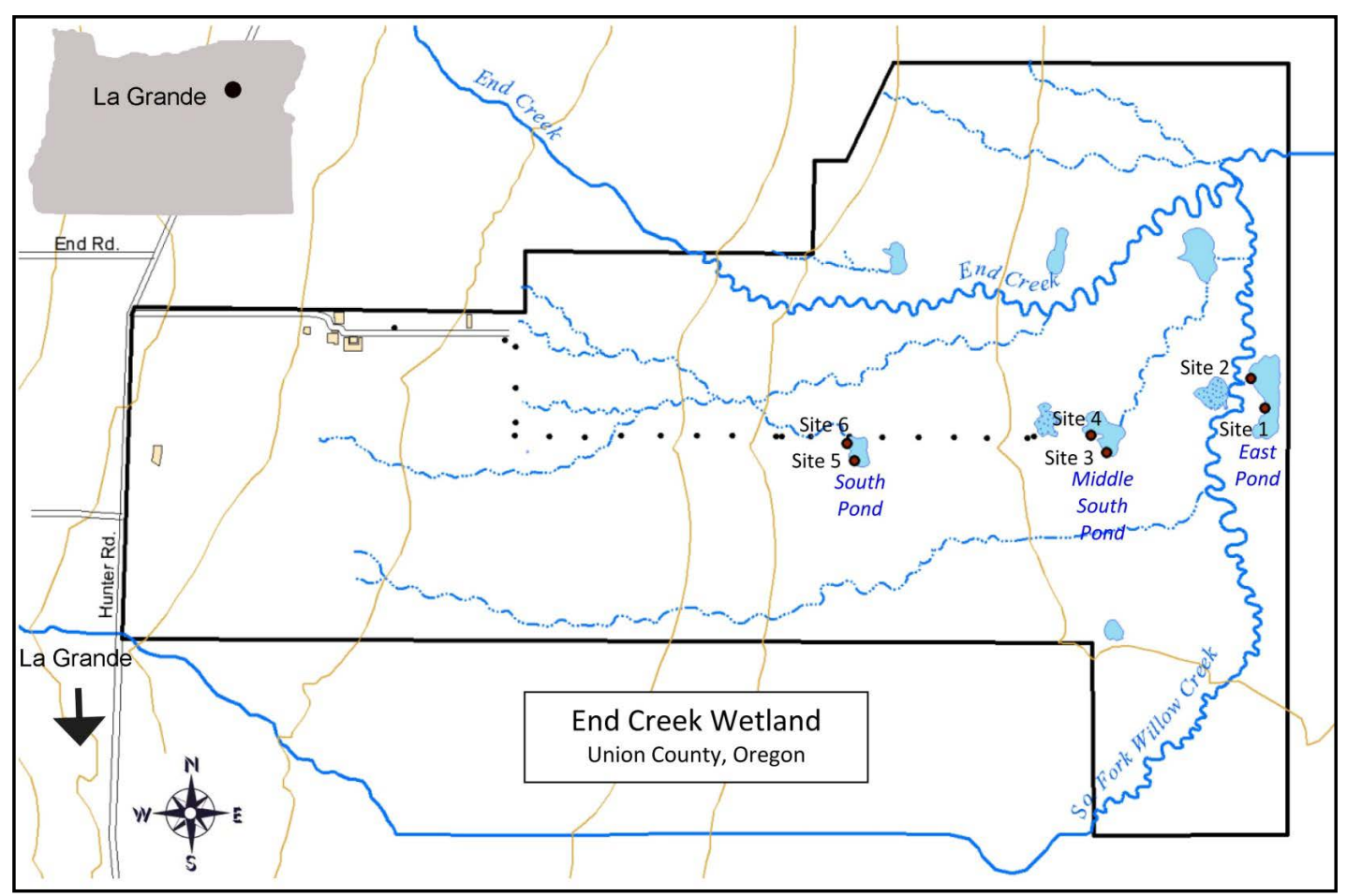

Figure 1. Location of the study site. End Creek drains part of the Mount Emily massif near the communities of La Grande and Island City in Eastern Oregon. The locality is 8 miles north of Island City, Oregon. Collection sites are indicated numerically. Inset shows state of Oregon and approximate location of La Grande. Black dots indicate the location of a primitive road. 
three ponds sampled in this study vary in water source and topography. The East Pond is fed by ground water and over-bank waters from nearby Willow Creek. The South Pond is fed by a spring, and the Middle South Pond is fed by ground water. The site is host to many native plants and animals, and the East Pond hosts a population of the endangered Columbia Spotted Frog (Rana luteiventris). The End Creek wetland is fed by drainages that pass through heavily grazed public and private lands. Deer and elk frequent the surrounding terrain, and a large variety of waterfowls utilize the waters. Thus, the potential for fecal contamination of the End Creek waters is high. In order to assess the fecal contamination, springtime coliform populations were monitored in the three End Creek ponds mentioned above. This has allowed us to establish a Total Coliform and a Fecal Coliform baseline to serve as reference for future water quality investigations.

\section{Methods}

Collection: Between 2009 and 2011, each pond was sampled between mid-February and mid-May. Exact dates varied from year to year. Water samples were collected from two different locations in each pond (Site 1, Site 2, etc.; Figure 1). Samples were collected in sterile $250 \mathrm{ml}$ polypropylene bottles. One bottle was collected from each site. Care was taken not to disturb sediments in collection zones during collection. Latitude and longitude were determined for each site (East Pond site 1: 45.46101N, 118.02010W; East Pond site 2: 45.46156N, 118.0204W; Middle South Pond site 3: 45.46013N, 118.02433W; Middle South Pond site 4: 45.46046N, 118.02475W; South Pond site 5: 45.45992N, 118.03107W; South Pond site 6: 45.46024N, 118.03128W).

Membrane filtration: After collection, all samples were immediately transported to the laboratory at ambient temperature in a backpack. A standard membrane filtration approach was then applied to load the samples onto membrane. Briefly, $150 \mathrm{ul}$ of each water sample was added to $50 \mathrm{ml}$ of sterile water in the sample reservoir connected to a filter funnel containing a $47 \mathrm{~mm}$ GN-6 (0.45 uM-Pall Corporation) filter that is able to block and retain bacteria such as Escherichia coli. Vacuum was applied until all liquid passed through the filter.

Cultivation: Filters loaded with samples were transferred by sterile forceps to either Eosine Methylene Blue (EMB) or MacConkey's agar plates. Three plates were prepared from each site and incubated at $37^{\circ} \mathrm{C}$ for 48 hours. After 48 hours at $37^{\circ} \mathrm{C}$, the agar plates were removed from incubation and positive colonies were counted after 48 hours. EMB is a differential and selective medium commonly used for detection of coliform bacteria, including Escherichia coli [15] [16]. It employs the selective agents eosin Y and methylene blue to restrict growth of gram-positive organisms, usually used to detect coliform bacteria from water and food sources. The coliform organisms produce dark purple colonies due to the acid produced from fermentation of the dimeric sugar lactose. On EMB agar, Escherichia coli, Enterobacter aerognes, and some Citrobacter species will form a green metallic sheen over the dark purple colony. Because there is some indication that the ability to positively identify Fecal Coliforms like Escherichia coli can vary significantly on EMB medium [15] [17], we used MacConkey medium to obtain a more accurate estimate of Fecal Colifom populations (primarily E. coli and Enterobacter aerogenes). MacConkey Agar is a selective and differential medium often employed to detect Fecal Coliforms, especially E. coli. While not commonly used in environmental testing strategies, MacConkey Agar is a stringent indicator of the Escherichia coli and Enterobacter aerogenes found in populations of coliforms derived from raw sewage (the so-called Fecal Coliforms [4] [15]-[17]). It contains bile salts, lactose, crystal violet, and neutral red. The bile salts select for those enteric bacteria that can survive high concentrations of bile salts found in the gastrointestinal tract. Enteric bacteria that are able to ferment lactose $\left(\mathrm{lac}^{+}\right)$induce a $\mathrm{pH}$ change that causes bile salts to precipitate and neutral red to accumulate in the colony. Colonies producing a deep pink color are presumed Enterobacter aerogenes and those producing deep red color and a zone of precipitated bile are presumed Escherichia coli. Both colony types were counted and counts combined for enumeration of the Fecal Coliform population.

\section{Results}

Variation of Total Coliform and lactose positive Fecal Coliforms (E. coli and Enterbacter aerogenes) between ponds: Each pond was sampled in two locations, each location was loaded onto three membrane filters, and the two locations were combined to obtain the average estimates of coliform load for each pond. Comparison of Total Coliforms and lac + Fecal Coliforms amongst the ponds for each collection date is shown for all three years in Figure 2. Single Factor Analysis of Variance (ANOVA) indicates that on most dates over the three year period there are significant differences in Total Coliform numbers between the ponds (on 3/28/2010 $\mathrm{F}=33.0$ 

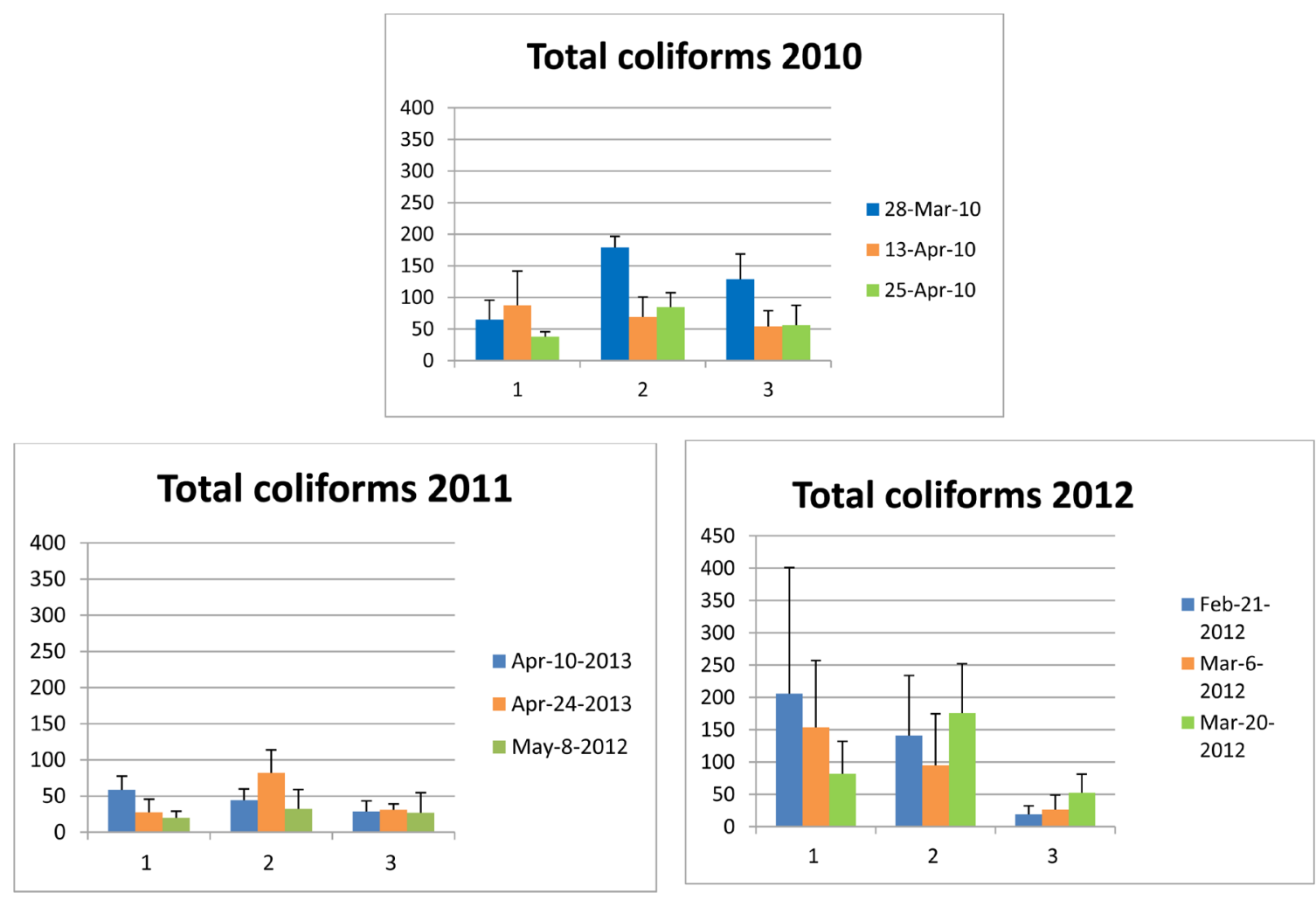

(a)
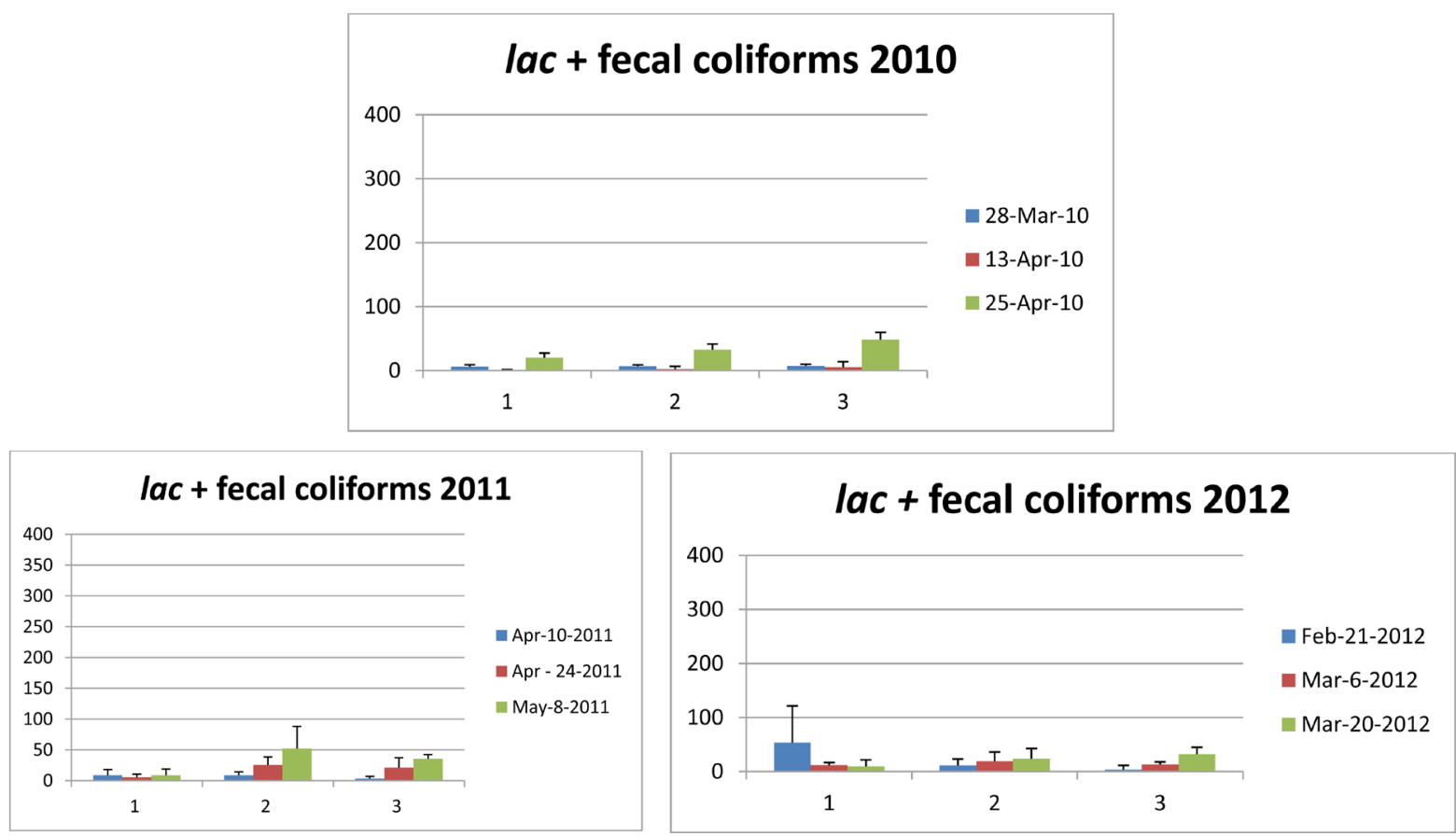

(b)

Figure 2. (a) Comparison of total coliform loads in each pond on different collection dates for each of the study years. $1=$ South Pond, 2 = Middle South Pond, and 3 = East Pond. Error bars represent the standard deviation of the average. Coliform numbers are reported in colonies $/ \mathrm{ml}$. (b) Comparison of lac + coliform load (presumed E. coli and Enterobacter aerogenes) in each pond on different collection dates for each of the study years. 1 = South Pond, $2=$ Middle South Pond, and $3=$ East Pond. Error bars represent the standard deviation of the average. Coliform numbers are reported in colonies $/ \mathrm{ml}$. 
and $\mathrm{F}_{\text {crit }}=3.6$, on $4 / 25 / 2010 \mathrm{~F}=4.4$ and $\mathrm{F}_{\text {crit }}=3.9$, on $4 / 10 / 2011 \mathrm{~F}=5.1$ and $\mathrm{F}_{\text {crit }}=3.7$, on $4 / 24 / 2011 \mathrm{~F}=12$ and $\mathrm{F}_{\text {crit }}=3.7$, on $2 / 21 / 2012 \mathrm{~F}=4.6$ and $\mathrm{F}_{\text {crit }}=3.5$, on $3 / 6 / 2012 \mathrm{~F}=5.6$ and $\mathrm{F}_{\text {crit }}=3.5$, and on $3 / 20 / 2012 \mathrm{~F}=10.1$ and $F_{\text {crit }}=3.6$ ) while on two dates there were no significant differences between the ponds (on 4/13/2010 F $=1.1$ and $F_{\text {crit }}=3.7$ and on 5/8/2011 0.7 and $F_{\text {crit }}=3.7$ ). Similarly, single factor ANOVA comparing ponds shows significant differences in the lac + coliforms in some cases (on 4/13/2010 F $=9.7$ and $\mathrm{F}_{\text {crit }}=3.7$, on $4 / 10 / 2011 \mathrm{~F}=$ 4.4 and $\mathrm{F}_{\text {crit }}=3.7$, on $5 / 8 / 2011 \mathrm{~F}=5.9$ and $\mathrm{F}_{\text {crit }}=3.6$, on $3 / 20 / 2012 \mathrm{~F}=10.1$ and $\mathrm{F}_{\text {crit }}=3.6$ ) but not in others (on $3 / 28 / 2010 \mathrm{~F}=0.1$ and $\mathrm{F}_{\text {crit }}=3.7$, on $4 / 25 / 2010 \mathrm{~F}=1.6$ and $\mathrm{F}_{\text {crit }}=3.7$, on $4 / 24 / 2011 \mathrm{~F}=2.6$ and $\mathrm{F}_{\text {crit }}=3.9$, on $2 / 21 / 2012 \mathrm{~F}=3.5 \mathrm{~F}_{\text {crit }}=3.5$, on $3 / 6 / 2012 \mathrm{~F}=0.6$ and $\mathrm{F}_{\text {crit }}=3.5$ ).

Total Coliform and Fecal Coliform springtime numbers vary from year to year: Sampling over a consecutive three-year period provided the opportunity to generate a multi-year baseline for Total Coliform and Fecal Coliform numbers in the three study ponds. Results for the mid-spring collection date (late March-early April of each year) are shown in Figure 3. Single Factor Analysis of Variance (ANOVA) shows that with Total Coliforms there is not a significant difference from year to year in the South Pond $\left(F=0.7, F_{\text {crit }}=3.7\right)$. As with the

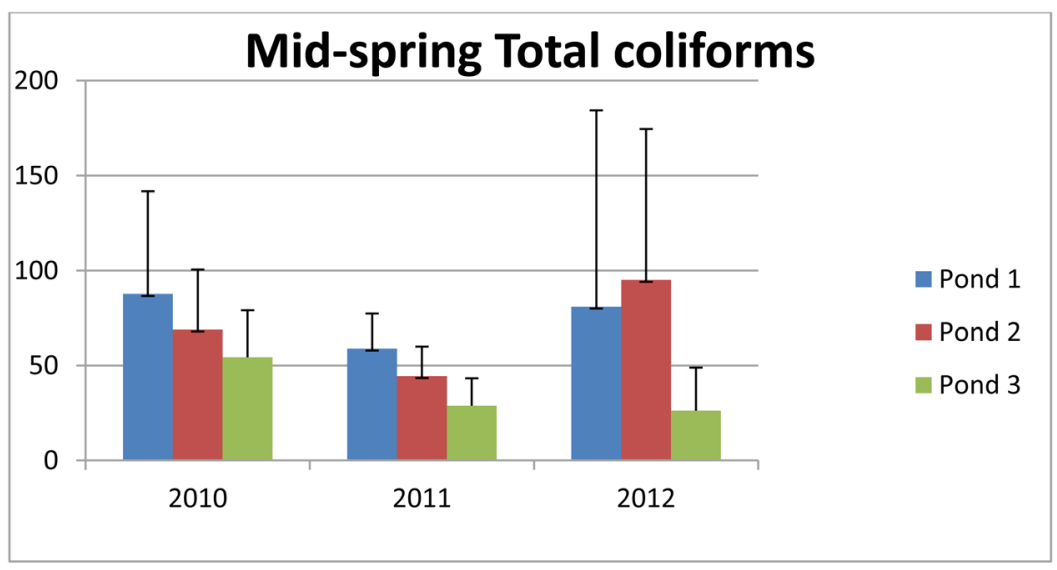

(a)

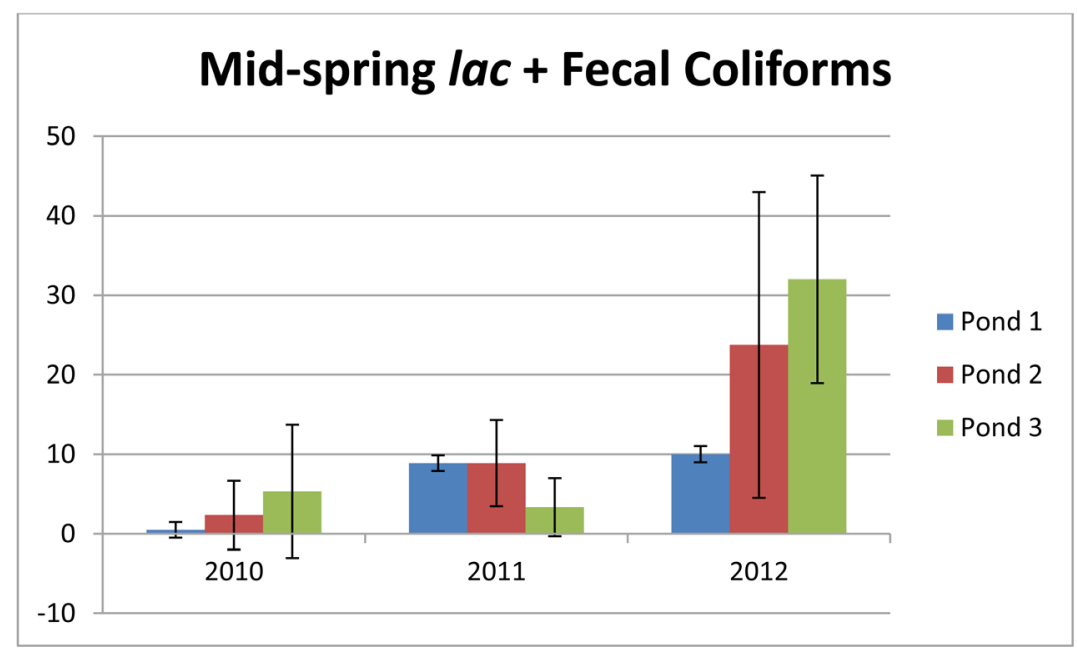

(b)

Figure 3. (a) Total coliforms from a mid-spring collection date (late March-early April) for 2010, 2011, and 2012. Pond 1 = South Pond, Pond 2 = Middle South Pond, and Pond 3 = East Pond. Error bars were calculated using standard deviation. Coliform numbers are reported in colonies $/ \mathrm{ml}$. (b) The lac+ coliforms from a mid-spring collection date (late March-early April) for 2010, 2011, and 2012. Pond $1=$ South Pond, Pond 2 = Middle South Pond, and Pond 3 = East Pond. Error bars for three replicate samples were calculated using standard deviation. Coliform numbers are reported in colonies $/ \mathrm{ml}$. 
South Pond, the East Pond exhibited no significant differences from year to year in the Total Coliform counts $\left(\mathrm{F}=2.4, \mathrm{~F}_{\text {crit }}=3.7\right)$; however, in the Middle South Pond there were significant differences from year to year $\left(\mathrm{F}=49.2, \mathrm{~F}_{\text {crit }}=3.7\right)$. Fecal Coliform numbers also varied, sometimes dramatically, from year to year. Single Factor ANOVA showed significant differences from year to year in the Middle South Pond $\left(\mathrm{F}=7.4, \mathrm{~F}_{\text {crit }}=3.7\right)$ and the East Pond $\left(\mathrm{F}=33, \mathrm{~F}_{\text {crit }}=3.70\right.$, with no significant difference in mid-spring from year to year in the South Pond $\left(\mathrm{F}=1.5, \mathrm{~F}_{\text {crit }}=3.7\right)$.

Variation of Total Coliform and lac + Fecal Coliforms (E. coli and Enterbacter aerogenes) in each pond during a given spring: Inspection of Figure 2 shows that in most cases the averages do vary greatly and while the error bars often overlap, ANOVA tests show that in many cases a given pond yields significant differences in both Total Coliform and Fecal Coliform on different dates (data not shown). Exceptions in which coliform numbers did not vary significantly in a pond over the sampling period are: 2010 Total Coliforms in the South Pond $\left(\mathrm{F}=2.9, \mathrm{~F}_{\text {crit }}=3.7\right), 2011$ Total Coliforms in East Pond $\left(\mathrm{F}=0.01, \mathrm{~F}_{\text {crit }}=3.7\right), 2011$ Fecal Coliforms in the South Pond $\left(\mathrm{F}=0.3, \mathrm{~F}_{\text {crit }}=3.7\right), 2012$ Total Coliforms in the South Pond $\left(\mathrm{SF}=1.6, \mathrm{~F}_{\text {crit }}=3.5\right), 2012$ Total Coliforms in the Middle South Pond $\left(\mathrm{F}=2, \mathrm{~F}_{\text {crit }}=3.5\right)$, and 2012 Fecal Coliforms in the Middle South Pond $(\mathrm{F}=$ $1.9, \mathrm{~F}_{\text {crit }}=3.5$ ).

Ratios of Total Coliforms/Fecal Coliforms: Because the Fecal Coliforms are a subset of the Total Coliforms, the ratio of Fecal Coliforms to Total Coliforms for each pond on each collection date is shown in Figure 4. In many cases the ratio is very low-below 0.1 (see all ponds: April 13, 2010; March 28, 2010; March 6, 2012; Feb 21, 2012). In some cases it was above 0.5 (all three ponds on April 25, 2010 as well as the South and Middle South Pond on March 20, 2012). In one case the ratio was 1 (Middle South Pond March 20,2012) and in two cases, the ratio was above 1 (East and Middle South Ponds on May 8, 2011).

\section{Discussion}

Wetlands management in the United States has become more common in the past two decades with the implementation of the North American Wetlands Conservation Act of 1989, and many agencies and conservation coalitions have invested significant effort in wetlands restoration. Monitoring water quality in restored ecosystems is a critical aspect of these management projects, and fecal contamination, with its attendant influx of organic matter and pathogenic microbes, is one of the important measures of water quality. Because of this, we monitored springtime coliform populations for three years to establish a base line for the coliform load at the End Creek Restoration Wetland. Since the total population of coliform bacteria is comprised of a variety of soil bacteria in addition to fecal coliforms found in raw animal waste, we utilized an approach that allowed us to detect colony-forming units (CFU) for both Total Coliforms and Fecal Coliforms. The Total Coliform numbers ranged from 8 - $344 \mathrm{CFU} / \mathrm{ml}$, and the Fecal Coliforms from 3 - 53 CFU/ml. Note that as per the Total Coliform Rule implemented by the EPA in 1990, the accepted EPA standard for Fecal Coliforms in drinking water is 0/100 ml and in recreational water is $200 \mathrm{CFU} / 100 \mathrm{ml}(2 / \mathrm{ml})$. Thus, at times Fecal Coliform loads in the End Creek ponds are beyond the recommended safety margin. Although the restoration area is not utilized for recreation, it is used for research and educational field trips by Eastern Oregon University. These results suggest that appropriate care should be taken (such as hand-washing and avoiding activities that splash water into the face) when collecting samples for research or educational purposes.

While there are many published studies addressing coliform loads in wetlands, most occur during part of only one year and do not provide a multi-year perspective. Our study was conducted over a three-year period, providing us with the opportunity to make a longitudinal comparison of coliform numbers over a three-year period. The data show that in any given year, Fecal and Total Coliform populations vary from pond to pond, suggesting that the sources of coliforms are not the same for each pond. In some cases, there are significant differences from year to year while in others there are no significant differences from year to year (see ANOVA comparisons and Figure 4). Results from ANOVA's and shown graphically in Figure 3 also indicate that there is a significant difference in Total Coliform numbers between the ponds on some dates within a given year, but not on other dates. Other studies have yielded similar results. For example, Dorsey et al. [13] showed that in the Ballona Wetlands saltwater marsh restoration site $E$. coli and Total Coliform populations vary not only from month to month, but also from hour to hour. Another study conducted in Saskatchewan, Canada, measured substantial monthly shifts in coliform numbers throughout a six-month monitoring period of a pond at the center of a prairie wetland [8]. An additional recent study [18] also detected significant fluctuation in coliform numbers in tidal 


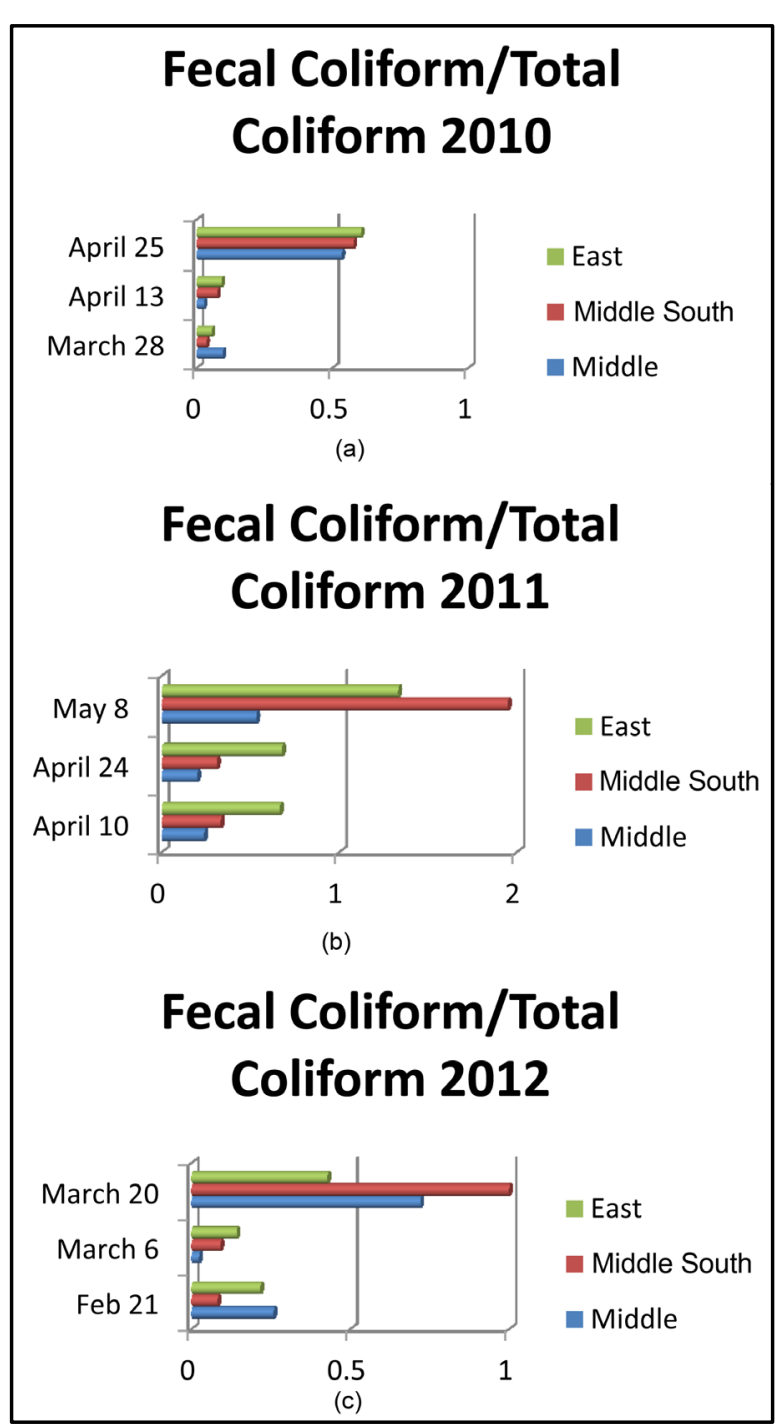

Figure 4. Ratio of Fecal Coliform/Total Coliform was calculated for each collection date. The ratio was determined by summing numbers of Total Coliform $/ \mathrm{ml}$ in each of the three replicates for each sample (EMB plate) on a given date and dividing that number by the total number of Fecal Coliforms (MacConkey Plate) on the same date.

wetlands, dairy wetlands, and artificial wetlands, and in some cases attributed these variations to precipitation (rainfall) events. These examples suggest that significant fluctuation of coliform populations is the norm, and our results appear to be no exception.

The data presented herein strongly suggest that coliform populations at End Creek fluctuate regularly throughout the spring and from year to year. While the flucuations are not unexpected, the causes of this fluctuation are difficult to firmly establish because tracking down sources of bacteria is a very difficult task. This task, termed source typing, is currently accomplished using cumbersome strategies that match antibiotic resistance profiles of potential source isolates with those in the waterways. A number of studies have been aimed at developing methods based upon Polymerase Chain Reaction for detecting strain specific differences in nucleotide sequence of the E. coli genome [19] [20] Johnson and Corsini unpublished data), but none of them appear to have sufficient resolution for accurate source-typing. However, despite the fact that the precise sources of coliforms at the End Creek site have not been identified, it is possible to comment in general about the fluctuating coliform numbers. All samples in our study were collected during spring snowmelt runoff, which was attended variably by rain and 
snow. The ponds were all swollen by spring flooding, which is expected to flush coliform bacteria out of the soil and feces from wild and domestic animals. Another factor contributing to fluctuating coliform numbers is the presence of waterfowl that use the ponds during their spring migration. Such waterfowl are known to harbor strains of Escherichia coli, for example O1:K1:H7 [21], which are pathogenic to humans. Many other animals are known to reservoir Fecal Coliforms, including pond turtles [22] and even the common bullfrog, Rana catesbeiana [23] [24]. Since the restoration efforts began in 2006, the End Creek ponds have been overrun by large numbers of Rana catesbeiana and it is possible that some of the Fecal Coliform load that we have detected originates from those animals.

\section{Conclusion}

In conclusion, this study indicates that in the springtime, numbers of both Total Coliforms and Fecal Coliforms can vary significantly within a given pond and among ponds in restored wetlands. It is also apparent that these numbers sometimes don't vary significantly within and between some ponds. In addition, our study shows that coliform abundance in a given pond can vary from year to year within some ponds, and that in some cases there is no significant variation. These results are consistent with other recently published studies, and suggest that it is very difficult to predict Total Coliform and Fecal Coliform loads at any given time and in any given place.

\section{Acknowledgements}

The studies were conducted with cooperation from the End Creek landowner and the Blue Mountains Conservancy. Publication costs were paid through a small grant from Eastern Oregon University's Office of Academic Affairs. We thank Dr. John Rinehart for helpful discussions throughout the course of this study.

\section{References}

[1] Karim, M.R., Manshadi, F.D., Karpiscak, M.M. and Gerba, C.P. (2004) The Persistence and Removal of Enteric Pathogens in Constructed Wetlands. Water Research, 38, 1831-1837. http://dx.doi.org/10.1016/j.watres.2003.12.029

[2] Graczyk, T.K. and Lucy, F.E. (2007) Quality of Reclaimed Waters: A Public Health Need for Source Tracking of Wastewater-Derived Protozoan Enteropathogens in Engineered Wetlands. Transactions of the Royal Society of Tropical Medicine and Hygiene, 101, 532-533. http://dx.doi.org/10.1016/j.trstmh.2007.02.018

[3] Cohen, J. and Shuval, H.I. (1973) Coliforms, Fecal Coliforms, and Fecal Streptococci as Indicators of Water Pollution. Water, Air, and Soil Pollution, 2, 85-95. http://dx.doi.org/10.1007/BF00572392

[4] Hoadley, A.W. (1977) Bacterial Indicators/Health Hazards Associated with Water. ASTM International, 635, 3-59. http://dx.doi.org/10.1520/stp635-eb

[5] Gordon, D.M. (2001) Geographical Structure and Host Specificity in Bacteria and the Implications for Tracing the Source of Coliform Contamination. Microbiology, 147, 1079-1085.

[6] Vymazal, J. (2005) Removal of Enteric Bacteria in Constructed Treatment Wetlands with Emergent Macrophytes: A Review. Journal of Environmental Science and Health, 40, 1355-1367. http://dx.doi.org/10.1081/ESE-200055851

[7] Liwimbi, L., Graves, A.K., Israel, D.W., Heugten, E.V., Robinson, B., Cahoon, C.W. and Lubbers, J.F. (2010) Microbial Source Tracking in a Watershed Dominated by Swine. Water, 2, 587-604. http://dx.doi.org/10.3390/w2030587

[8] Brunet, N.N. and Westbrook, C.J. (2012) Wetland Drainage in the Canadian Prairies: Nutrient, Salt and Bacteria Characteristics. Agriculture, Ecosystems \& Environment, 146, 1-12. http://dx.doi.org/10.1016/j.agee.2011.09.010

[9] Sauvé, S., Aboulfadl, K., Dorner, S., Payment, P., Deschamps, G. and Prévost, M. (2012) Fecal Coliforms, Caffeine and Carbamazepine in Stormwater Collection Systems in a Large Urban Area. Chemosphere, 86, 118-123. http://dx.doi.org/10.1016/i.chemosphere.2011.09.033

[10] Eppley, R.W., Carlucci, A.F., Holm-Hansen, O., Kiefer, D., McCarthy, J.J. and Williams, P.M. (1972) Evidence for Eutrophication in the Sea near Southern California Coastal Sewage Outfalls, July, 1970. CalCOFI Report, California Marine Research Communication, 16, 74-83.

[11] Mallin, M.A., McIver, M.R., Wells, H.A., Parsons, D.C. and Johnson, V.L. (2005) Reversal of Eutrophication Following Sewage Treatment Upgrades in the New River Estuary, North Carolina. Estuaries, 28, 750-760. http://dx.doi.org/10.1007/BF02732912

[12] Jarvie, H.P., Neal, C. and Withers, P.J. (2006) Sewage-Effluent Phosphorus: A Greater Risk to River Eutrophication than Agricultural Phosphorus? Science of the Total Environment, 360, 246-253. http://dx.doi.org/10.1016/j.scitotenv.2005.08.038 
[13] Dorsey, J.H., Carter, P.M., Bergquist, S. and Sagarin, R. (2010) Reduction of Fecal Indicator Bacteria (FIB) in the Ballona Wetlands Saltwater Marsh (Los Angeles County, California, USA) with Implications for Restoration Actions. Water Research, 44, 4630-4642. http://dx.doi.org/10.1016/j.watres.2010.06.012

[14] Elmund, G.K., Allen, M.J. and Rice, E.W. (1999) Comparison of Escherichia coli, Total Coliform, and Fecal Coliform Populations as Indicators of Wastewater Treatment Efficiency. Water Environment Research, 71, 332-339. http://dx.doi.org/10.2175/106143098X121752

[15] Grabow, W.O.K., Hilner, C.A. and Coubrough, P. (1981) Evaluation of Standard and Modified M-FC, MacConkey, and Teepol Media for Membrane Filtration Counting of Fecal Coliforms in Water. Applied and environmental Microbiology, 42, 192-199.

[16] Levine, M. (1918) Differentiation of B. Coli and B. Aerogenes on a Simplified Eosin-Methylene Blue Agar. The Journal of Infectious Diseases, 23, 43-47.

[17] Grabow, W.O. and Du Preez, M. (1979) Comparison of m-Endo LES, MacConkey, and Teepol Media for Membrane Filtration Counting of Total Coliform Bacteria in Water. Applied and Environmental Microbiology, 38, 351-358.

[18] Hogan, J.N., Daniels, M.E., Watson, F.G., Conrad, P.A., Oates, S.C., Miller, M.A. and Miller, W.A. (2012) Longitudinal Poisson regression to Evaluate the Epidemiology of Cryptosporidium, Giardia, and Fecal Indicator Bacteria in Coastal California Wetlands. Applied and Environmental Microbiology, 78, 3606-3613. http://dx.doi.org/10.1128/aem.00578-12

[19] Martinez-Murcia, A.J., Anton, A.I. and Rodriguez-Valera, F. (1999) Patterns of Sequence Variation in Two Regions of the 16S rRNA Multigene Family of Escherichia coli. International Journal of Systematic Bacteriology, 49, 601-610. http://dx.doi.org/10.1099/00207713-49-2-601

[20] Dombek, P.E., Johnson, L.K., Zimmerley, S.T. and Sadowsky, M.J. (2000) Use of Repetitive DNA Sequences and the PCR to Differentiate Escherichia coli Isolates from Human and Animal Sources. Applied and Environmental Microbiology, 66, 2572-2577. http://dx.doi.org/10.1128/AEM.66.6.2572-2577.2000

[21] Johnson, T.J., Kariyawasam, S., Wannemuehler, Y., Mangiamele, P., Johnson, S.J., Doetkott, C. and Nolan, L.K. (2007) The Genome Sequence of Avian Pathogenic Escherichia coli Strain O1: K1: H7 Shares Strong Similarities with Human Extra-Intestinal Pathogenic E. coli Genomes. Journal of Bacteriology, 189, 3228-3236. http://dx.doi.org/10.1128/JB.01726-06

[22] Harwood, V.J., Butler, J., Parrish, D. and Wagner, V. (1999) Isolation of Fecal Coliform Bacteria from the Diamondback Terrapin (Malaclemys terrapin centrata). Applied and Environmental Microbiology, 65, 865-867.

[23] Gray, M.J., Rajeev, S., Miller, D.L., Schmutzer, A.C., Burton, E.C., Rogers, E.D. and Hickling, G.J. (2007) Preliminary Evidence that American Bullfrogs (Rana catesbeiana) Are Suitable Hosts for Escherichia coli O157: H7. Applied and Environmental Microbiology, 73, 4066-4068. http://dx.doi.org/10.1128/AEM.02905-06

[24] Dipineto, L., Gargiulo, A., Russo, T.P., De Luca Bossa, L.M., Borrelli, L., d' Ovidio, D. and Fioretti, A. (2010) Survey of Escherichia coli 0157 in Captive Frogs. Journal of Wildlife Diseases, 46, 944-946. http://dx.doi.org/10.7589/0090-3558-46.3.944 